\title{
The Relationship between the Acute Confusing State and the Comorbidities of the Elderly Patient
}

\begin{abstract}
VALERIA CARMEN ALBU1, RALUCA ELENA SANDU2*, ANDREEA LILI BARBULESCU³, ELENA ANCA TARTEA ${ }^{1}$, EMILIA BURADA4, OANA TAISESCU ${ }^{5}$, FLORENTIN ANANU VREJ U6, MIHAI VIRGIL BOLDEANU', LIDIA BOLDEANU ${ }^{8}$, AURELIA ENESCU, DENISA PASCOVEANU ${ }^{1}$, ANDREEA CRISTINA STOIAN ${ }^{10}$, BOGDAN CATALIN ${ }^{4}$, ANCA EMANUELA MUSATESCU 6

'University of Medicine and Pharmacy of Craiova, Neurology Department, 2 Petru Rares Str., 200349, Craiova, Romania 2University of Medicine and Pharmacy of Craiova, Biochemistry Department, 2 Petru Rares Str., 200349, Craiova, Romania 3University of Medicine and Pharmacy of Craiova, Pharmacology Department, 2 Petru Rares Str., 200349, Craiova, Romania ${ }^{4}$ University of Medicine and Pharmacy of Craiova, Physiology Department, 2 Petru Rares Str., 200349, Craiova, Romania 5University of Medicine and Pharmacy of Craiova, Anatomy Department, 2 Petru Rares Str., 200349, Craiova, Romania ${ }^{6}$ University of Medicine and Pharmacy of Craiova, Rheumatology Department, 2 Petru Rares Str., 200349 Craiova, Romania 7 University of Medicine and Pharmacy of Craiova, Immunology Department, 2 Petru Rares Str., 200349 Craiova, Romania 8 University of Medicine and Pharmacy of Craiova, Microbiology Department, 2 Petru Rares Str., 200349 Craiova, Romania ${ }^{9}$ University of Medicine and Pharmacy of Craiova, Internal Medicine Department, 2 Petru Rares Str., 200349 Craiova, Romania ${ }^{10}$ University of Medicine and Pharmacy of Craiova, Infectious Disease Department, 2 Petru Rares Str., 200349 Craiova, Romania
\end{abstract}

The aim of the study was to assess the correlations between the acute confusing syndrome and different comorbidities found in a group of 126 elderly patients with this diagnosis, who were admitted to the Neurology Clinic of the Neuropsychiatry Hospital of Craiova. The main syndromes highlighted at the neurological examination were confusing, pyramidal and vestibular syndromes. The acute confusing syndrome has a multifactorial etiology, due to the wide range of comorbidities encountered in elderly patients. In our study the most frequent comorbidities were cardiovascular pathology, diabetes mellitus, dyslipidemia, cerebrovascular renal, hepatic pathology

Keywords: acute confusing state, elderly patients, comorbidities.

Delirium represents an acute confusing state which develops quickly and presents fluctuations during the day [1]. Acute confusing state (ACS), which is one of the most common psychiatric syndromes, it is frequently present in elderly hospitalized patients [2], as it represents $10-25 \%$ of all acute admissions to the hospital [3]. ACS is linked to a functional decline of the hospitalized patient and to a risk of complications achieved during hospitalization and it is also associated with an increased hospital stay, with a need for long-term care, and with an increased short-term mortality rate [4]. ACS predisposing factors in hospitalized patients regardless the cause of admission include: age, male gender, drugs [5-7], both somatic and metabolic disorders $[5,8,9]$ dementia $[5,6,9,10]$, and focal brain injuries [5, 7-9], especially stroke [5]. The stroke acute phase has a common complication known as post-stroke delirium [10-11].

The alteration of both the state of consciousness and cognition, focused on the inability to orientate and to pay attention characterizes ACS [12]. Taking into account that all cognitive processes are based on the main characteristics of the state of consciousness, including both lucidity and clarity, they will be directly proportional affected with the degree of consciousness impairment. Thus, the diversity of the syndrome's clinical forms results. This interdependence between the cognitive functions, meaning that if any of them is being altered the others will suffer too, leads to the variate spectrum of the clinical features. CAM (Assessment Method) and DSM 5 (Diagnostic and statistical Manual of Mental disorders) are used in order to support the ACS diagnosis as they include the essential diagnostic criteria. Nevertheless, by using Delirium Rating Scale the ACS severity can be assessed.
The elements that surely define ACS include sudden onset (hours, days), various clinical characteristics, acute evolution with fluctuations during the day and global worsening during the night [13-14].

There are three clinical forms:

-Hyperactive form (representing $20 \%$ of all the cases): characterized by both psychomotor agitation and psychotic symptoms.

-Hypoactive form (representing $29 \%$ of all cases): characterized by apathy, lethargy, lack of cooperation.

-Mixed form (representing $43 \%$ of the cases): combining elements of both hyper and hypoactive forms [14-15].

In what the pathophysiological point of view is concerned, metabolic disturbance as well as diffuse brain transmission influenced by the local and systemic factors cause the acute confusing syndrome. Neurotransmitters, such as acetylcholine and dopamine are involved in this process [16].

\section{Experimental part}

The aim of the study was to assess the correlations between the acute confusing syndrome and different comorbidities found in a group of elderly hospitalized patients, as well as, the correlations between personal features (age, gender, urban/rural area, educational level) and the incidence of this syndrome.

\section{Material and methods \\ We performed an observational retrospective study that included a number of 126 patients suffering from confusing syndrome who were admitted to the Neurology Clinic of the Neuropsychiatry Hospital of Craiova between 01.01.2017 and 31.12.2018. This study was conducted based on the analysis of their observation sheets.}


The analyzed paraclinic parameters included biological parameters (blood ionogram, blood count cell, coagulation tests [with Quick time], and erythrocyte sedimentation rate, C-reactive protein, lipidograma, serum glucose, total proteins, transaminase, urea, creatinine, urinalysis exam); 12-lead ECG; and non-contrast CT scan.

Data, recorded within $24 \mathrm{~h}$, included: age; gender; education level (less or more than eight years of schooling);comorbidities including arterial hypertension (meaning systolic blood pressure higher than $160 \mathrm{~mm} \mathrm{Hg}$ or diastolic blood pressure higher than $90 \mathrm{~mm} \mathrm{Hg}$ either before stroke or lasting one month after the onset of the vascular event, use of antihypertensive drugs); diabetes mellitus (defined as serum glucose level over1 $20 \mathrm{mg} / \mathrm{L}$ or treatment with antidiabetic drugs); hyperlipidemia (serum level of triglycerides over150mg/L or cholesterol serum level over230m $/ \mathrm{L}$ ); peripheral artery disease with intermittent claudication; previous vascular events including transient ischemic attack (TIA) or stroke; alcohol consumption more than300 g/week; cigarette smoking (more than 10 cigarettes a day or cessation less than5 years earlier). By using the Mini Mental State Evaluation (MMSE) we assessed the cognitive function of the patients included in the study. We also studied the mortality rate during hospitalization and we evaluated the functional outcome by using both the Barthel Index and the Rankin Scale.

\section{Results and discussions}

With regard to gender distribution, there was a higher proportion of the confusing syndrome in females (59\%), representing 74 cases, compared to male gender with a percentage of $41 \%$, representing 52 cases (fig 1.).

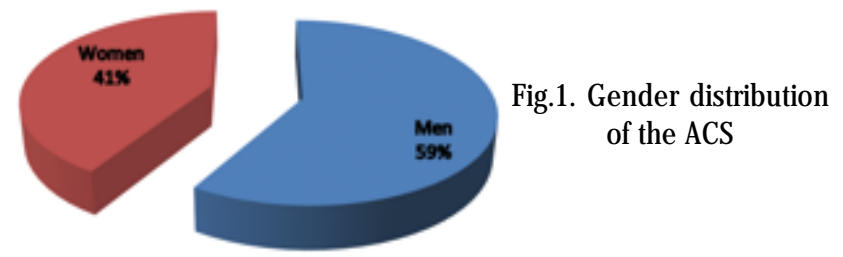

The statistics on the origin of the patients included in the study showed a higher incidence of the confusing syndrome in the rural area, 70 patients compared to 56 urban patients. In terms of gender distribution, it was noted that the incidence was higher in rural areas ( 36 male patients), compared to urban zones (18 patients), for the male gender the ratio between rural and urban areas was $2 / 1$. For female gender the same ratio was 38/34, it did not show significant differences as for the male gender (fig.2.).

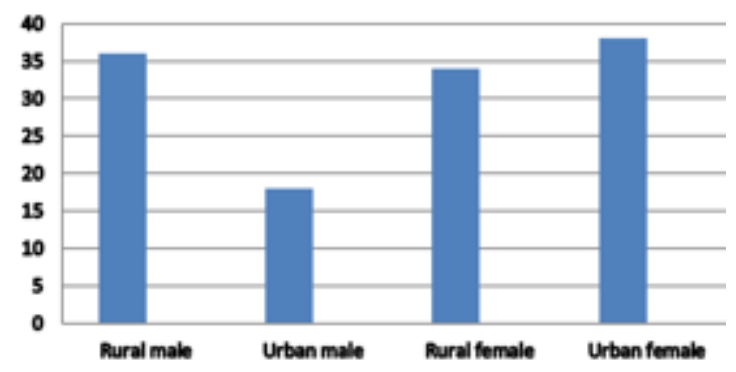

Fig.2. Distribution of ACS depending on the environmental of origin and gender

We noticed that in our study the onset age of the confusing syndrome is between 60 and 70 years with a peak between70-80 years, this information is similar to the information found in other published studies [17], according to which the elderly population is frequently affected by the acute confusing syndrome. The average age of the study group is $71,5 \pm 10$ and it is a little bithigher than the average age found in other studies (ID $65 \pm 10$ years.) [18]. Taking into account that this diagnosis affects mainly the elderly population, a link between the comorbidities found in this age group can represent a pathophysiological hypothesis [19-22]. Moreover, the average age in women is $72,3 \pm 8.5$ compared to the average age $(70.3 \pm 11.9)$ in men, so women tend to develop later this pathology.

We analyzed the occurrence of the confusing syndrome based on patients' age at admission. We did not record any cases between the age of 0 and 40 years. Between 4150 years of age, gender distribution was equal compared to the age interval of 51-60 years, where six cases of confusing syndrome were reported in men. The number of patients having this diagnosis increased in the next two decades of age, presenting a tendency to equalize in the $8^{\text {th }}-9^{\text {th }}$ decade, with a higher incidence of the female gender (fig.3.).

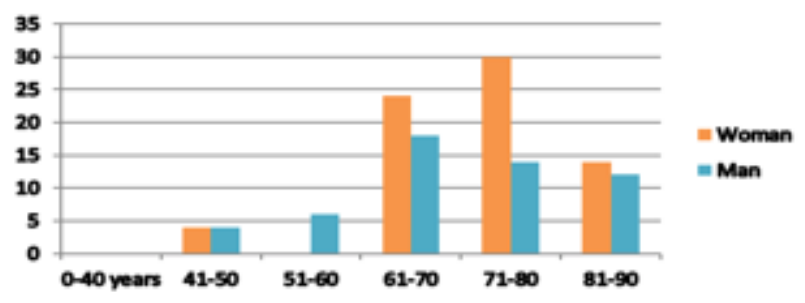

Fig.3. Distribution of ACS depending on the age

Statistics based on the educational level revealed an increased incidence of the confusing syndrome in patients without studies (49\%), compared to the patients with higher educational level (3\%) (fig.4.).

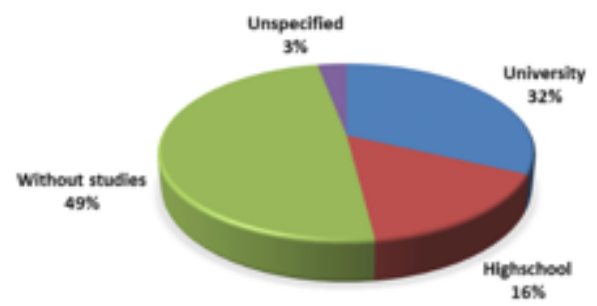

Fig.4. Distribution of ACS based on the educational level

In addition, taking into account the reasons for hospital admission of the patients suffering from confusing syndrome, we noticed that a number of 22 patients (representing 34.92\%) were admitted at the hospital only presenting a confusing state. Gait and balance disorders, that were present in 26 patients, followed by dizziness in 22 patients were the most common reasons for hospitalization. Apartfrom the reasons included in Table.1, swallowing, vision and language disorders as well as sleepiness and fatigue were frequently associated. Also included in this category but less frequently encountered (less than 10 cases) were temporal and spatial disorientation, upper right muscular hypotonia, decreased muscle strength (fig.5.).

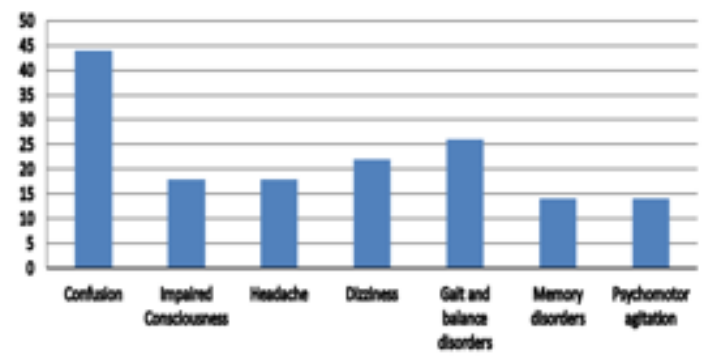

Fig.5. Reasons for hospital admission 
Table 1

CAUSES OF ACUTE CONFUSING SYNDROME

\begin{tabular}{|c|c|c|}
\hline neurological causes & non-neurological causes & often multifactorial origin \\
\hline stroke & hypoxia & intensive care ("ICU delirium") \\
\hline infectious encephalitis/meningoencephalitis & $\begin{array}{l}\text { hypoglycaemia, hyperglycaemia } \\
\text { hyponatraemia ("dilution } \\
\text { delirium"), hypernatraemia } \\
\text { hypocalcaemia, hypercalcaemia } \\
\text { hepatic, uraemic encephalopathy } \\
\text { vitamin B1 deficiency } \\
\text { (Wernicke's encephalopathy) } \\
\text { vitamin B12 deficiency }\end{array}$ & postoperative \\
\hline $\begin{array}{l}\text { CNS vasculitis (systemic erythematosus lupus, arteritis } \\
\text { with gigantic cells, periarteria nodosa), limbic } \\
\text { encephalitis }\end{array}$ & $\begin{array}{l}\text { Systemic colagenoses, } \\
\text { chrondrocalcinosis } \\
\text { hyperviscosity syndrome } \\
\text { acute porphyria }\end{array}$ & advanced cancer \\
\hline granulomatous meningoencephalitis ( $\mathrm{Tbc}$, sarcoidosis) & $\begin{array}{l}\text { endocrine disturbances } \\
\text { (hyperthyroidism, } \\
\text { hypothyroidism, } \\
\text { Cushing's disease, } \\
\text { adrenal/pituitary insufficiency) }\end{array}$ & older patients \\
\hline $\begin{array}{l}\text { non-convulsive status epilepticus } \\
\text { migraine }\end{array}$ & $\begin{array}{l}\text { drugs: levodopa, dopamin } \\
\text { agonists, anticholinergics, } \\
\text { antidepressants, antibiotics, } \\
\text { chemotherapeutics, intrathecal } \\
\text { medications, steroids, etc. } \\
\text { malignant neuroleptic syndrome } \\
\text { serotonin syndrome } \\
\text { alcohol withdrawal ("delirium } \\
\text { tremens"), benzodiazepine/ } \\
\text { barbiturates withdrawal } \\
\text { poisonings }\end{array}$ & \\
\hline tic brain imjury & & \\
\hline
\end{tabular}

The primary diagnosis of admission was confusing syndrome in 74 cases, the remaining 42 patients also presented one of the diagnostics mentioned in Table.1.

In what secondary diagnostics are concerned, HTA affected 37 patients, being the most frequently encountered, followed by atrial fibrillation in 17 patients, 15 patients presented metabolic disorders such as dyslipidemia, which is associated with a risk for cardiovascular disease. Another comorbidity commonly found in 15 patients ( 9 women and 6 men) was type II diabetes. Unbalanced glycemic status may be a consequence of the confusing state as we can see in ketoacidosis coma or diabetic acidosis. Chronic alcohol consumption was present in 7 patients, 2 patients presented hepatic encephalopathy, 3 patients had liver cirrhosis. Moreover, secondary diagnoses included viral hepatitis: 2 cases with hepatic B virus and five cases with hepatic $\mathrm{C}$ virus (fig.6.).
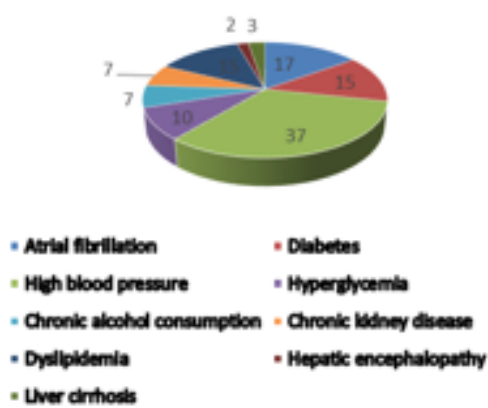

Fig.6. Main secondary diagnosis
The main syndromes highlighted at the neurological examination were confusing, pyramidal and vestibular syndromes. The prevalence of the pyramidal syndrome was noted in 39 patients (fig.7.).

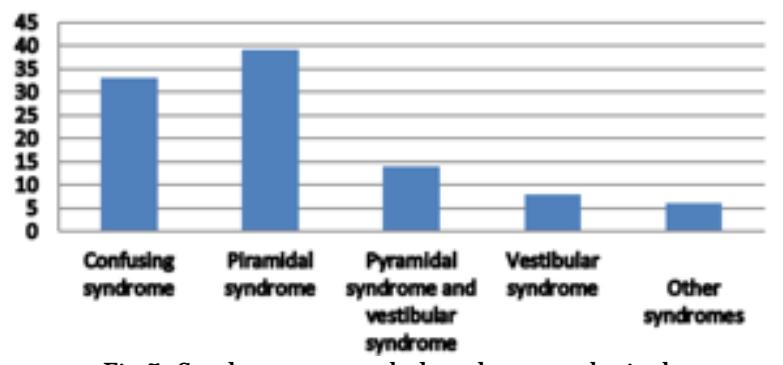

Fig.7. Syndromes revealed at the neurological exam.

Analysis of the computer tomography images showed a high proportion of cortical atrophy, which affected 39 patients, followed by stroke in 27 cases. The CT examination performed at the admission did not describe injuries in 43 patients. Among the CT evaluations we observed other aspects such as temporal-parietal tumor, cavern, subarachnoid cyst and meningioma, these aspects were seen in a total number of 5 patients, representing a percentage of $7.93 \%$. The graphical representation of CT results revealed a slightly increased incidence of cortical atrophy and cerebral lacunarism in men (fig.8.).

In patients with ischemic stroke, CT examination revealed the association between the confusing syndrome 


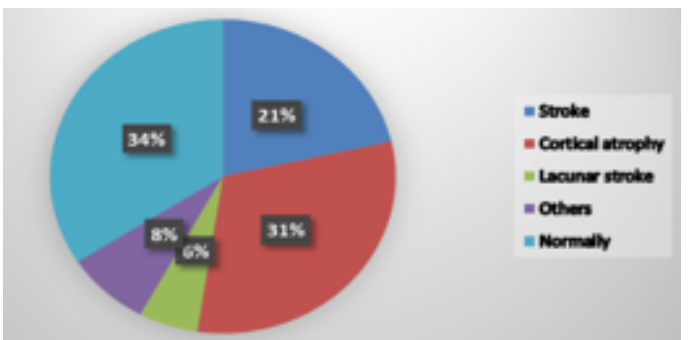

Fig.8. Results of CT examination

and the localization of ischemic lesion in the left-brain hemisphere ( 7 cortical and 9 subcortical).

The data obtained in our study support the data from other already published studies, the incidence of the confusing syndrome begins to rise after the age of 65 [23].

Cognitive impairment and dementia are considered important risk factors for delirium as cohort studies show. Moreover, according to this studies delirium was observed in groups that included patients suffering from dementia [24]. As both delirium and dementia have similarities in what both clinical and pathogenic characteristics are concerned, these two clinical entities may have a common pathogenic mechanism, and so, they can't be considered totally different diseases. Inflammation may play a role in the genesis of delirium and dementia, as both these clinical entities present elevated levels of inflammatory markers. Elevated cytokines level has an important role in causing cognitive dysfunction in patients suffering from dementia and delirium, as showed in other clinical studies [25].

In our study, 12 patients presented dementia and the CT examination revealed cortical atrophy in 39 patients ( 21 men and 18 women).

Delirium represents a post-stroke complication frequently encountered, which affects the patient's rehabilitation as it is linked with poor outcome. In patients suffering from post-stroke delirium, advanced age together with the severity of the vascular event contribute to a high long-term mortality [26-28]. In our study 27 patients presented ischemic stroke and delirium was more often observed in patients with left cortex ischemic stroke.

Also risk factors for the onset of delirium are considered the metabolic disorders including hypo and hyperglycemia, but more studies are needed in order to support this hypothesis [29-33].

However, glucose control still remains controversial nowadays. Mortality seems to be elevated by an intensive control of the glucose level (glucose target is between 4.5$6.0 \mathrm{mmol} / \mathrm{L}(81.0-108.1 \mathrm{mg} / \mathrm{dL}))$ compared to a conventional glucose control (glucose target being established under10.0 mmol/L (180.1 mg/dL)). The death risk may be increased by hypoglycemia encountered during intensive glucose control. Moreover, the rate of mortality is higher in non-diabetic patients that present hyperglycemia compared to patients that suffer from diabetes mellitus, the adaptive mechanisms of chronic hyperglycemia seem to be involved. Nevertheless, in patients with a critical health state mortality was linked to the glucose variability [34].

The correlation between delirium and glucose variability needs more studies in order to be properly understood, until now, it is only known that they are both associated with negative effects. Patients suffering from hyperactive delirium presented higher glucose levels than critical patients with non-hyperactive delirium. The activity of hypothalamic-pituitary-adrenal axis may be accelerated by this acute health condition leading, in consequence, to an increased release of cortisol and to a decreased insulin sensitivity, thus causing hyperglycemia [35-47]. In our study
15 patients presented diabetes mellitus, and 10 patients had hyperglycemia.

\section{Conclusions}

In most of the cases the etiology of the ACS syndrome is multifactorial, as it is the result of the imbalances produced due to the wide range of comorbidities encountered in elderly patients. In our study the most frequent comorbidities were in the first place cardiovascular pathology, followed by diabetes mellitus, dyslipidemia, renal, hepatic and, nevertheless, cerebrovascular pathology (ishemic sechelar stroke).

Patients suffering from confusing syndrome presented a wide variety of clinical symptoms including classical symptoms as well as nonspecific symptomatology as gait and balance disorders, headache and also dizziness.

At the imaging explorations the main feature presented by the patients included in the study was cortical atrophy, that represents a neuroimaging feature usually observed in elderly patients suffering from confusing syndrome.

\section{References}

1.**AMERICAN PSYCHIATRIC ASSOCIATION. DSM-5 TASK FORCE. Diagnostic and statistical manual of mental disorders: DSM-5. Arlington: American Psychiatric Publishing, 2013, p.596-601.

2.JITAPUNKUL, S., PILLAY, I., EBRAHIM, S. Delirium in newly admitted elderly patients: a prospective study. Q J Med, 83, 1992, p. 307-304. 3.COLE, M.G. Delirium in elderly patients. Am J Geriatr Psychiatry, 12, 2004, p. 7-21

4.LIPOWSKI, Z.J. Delirium in the elderly patient. N Engl J Med, 320, 1989 , p. $578-582$.

5.SCHOR, J.D., LEVKOFF, S.E., LIPSTITZ, L.A., REILLY, C.H., CLEARY, P.D., ROWE, J.W., EVANS, D.A. Risk factors for delirium in hospitalized elderly, JAMA, 267, 1992, p. 827- 831.

6.SUMNER, A.D., SIMONS, R.J. Delirium in the hospitalized elderly. Cleve Clin J Med, 61, 1994, p. $258-262$.

7.KOPONEN, H.J., STENBA, C.K.U., MATTILA, E., SOININEN, H., REINIKAINEN, K., RIEKKINEN, P.J. Delirium among elderly persons admitted to a psychiatric hospital: clinical course during the acute stage and one-year follow-up. Acta Psychiatr Scand, 79, 1989, p. 579585.

8.KOPONEN, H.J., RIEKKINEN, P.j. A prospective study of delirium in elderly patients admitted to a psychiatric hospital. Psychol Med, 23, 1993, p. 103-109.

9.POMPEI, P., FOREMAN, M., RUDBERG, M.A., INOUYE, S.K., BRAUND, V., CASSEL, C.K. Delirium in hospitalized older persons: outcomes and predictors. J Am Geriatr Soc, 42, 1994, p. 809-815.

10.OLDENBEUVING, A.W., DEKORT, P.L., JANSEN, B.P. Delirium in the acute phase after stroke: incidence, risk factors and outcome. Neurology, 76, 2011, p. 993-999.

11.SANDBERG, 0., FRALKLIN, K.A., BUCHT, G. Sleep apnea, delirium depressed mood, cognition and ADL ability after stroke.J AM Geritriatr SOC, 49, 2001, p. 391-397.

12.FRANCIS, J., AMINOFF, M., SCHMADER, E.K. Delirium and acute confusional states: Prevention, treatment, and prognosis. UpToDate, 2013, https://ww w.uptodate.com/contents/delirium-and-acuteconfusional-states-prevention-treatment-and-prognosis.

13.AKUNNE, A., O'MAHONY, R. Guideline Development Group: Diagnosis, prevention and management of delirium: Summary of NICE guidance. BMJ, 341, 2010, p. c3704.

14.SAXENA, S., LAWLEY, D. Delirium in elderly: a clinical review. Postgrad Med J, 85, 2009, p. 405-413.

15.SINGLER, B. Das postoperative Delirium. Geriatrie J ournal, 2, 2010, p. $41-42$.

16.O KEEFFE, S.T., NI, C.A. Anesthesia Br J : Postoperative delirium in elderly, 73, 1994, p. 673--687. 
17.LORENZL, S., FUSGEN, I., NOACHTAR, S. Acute Confusional States in the Elderly- Diagnosis and Treatment. Deutsches Arzteblatt, 109, no. 21, 2012, p. 391-400.

18.RAJ, D., GARG, R.K., MALHOTRA, H.S., et al. Acute confusional state/delirium: An etiological and prognostic evaluation. Ann Indian Acad Neurol, 17, no. 1, 2014, p. 30-34.

19.GEORGE, J., BLEASDALE, S., SINGLETON, S.J . Causes and prognosis of delirium in elderly patients admitted to a district general hospital. Age Ageing, 35, 2006, p. 350-364.

20.SCHORL, J.D., LEVKOFF, S.E., LIPSITZ, L.A., et al. Risk factors for delirium in hospitalized elderly. JAMA, 267, 1992, p. 827-831.

21.ROPPER, A.H., SAMUELS, M.A., KLEIN, J.P. Adams and Victor's Principles of Neurology, tenth edition, 2014, section 5, chapter 20, p. 421-433.

22.QU, J., CHEN, Y., LUO, G., ZHONG, H., XIAO, W., YIN, H. Delirium in the Acute Phase of Ischemic Stroke: Incidence, Risk Factors, and Effects on Functional Outcome. J Stroke Cerebrovasc Dis, 27, no. 10, 2018, p. 2641-2647.

23.INOUYE, S.K., WESTENDORP, R.G., SACZYNSKI, J.S. Delirium in elderly people. Lancet, 383, no. 9920, 2014, p. 911-922.

24.FONG, T.G., DAVIS, D., GROWDON, M.E., ALBUQUERQUE, A., INOUYE, S.K. The interface between delirium and dementia in elderly adults. Lancet Neurol, 14, no. 8, 2015, p. 823-832.

25.SIMONE, M.J., TAN, Z.S. The role of inflammation in the pathogenesis of delirium and dementia in older adults: a review, CNS Neurosci Ther, 17, no. 5, 2011, p. 506-513.

26.MELKAS, S., LAURILA, J.V., VATAJA, R., OKSALA, N., JOKINEN, H., POHJASVAARA, T., LEPPÄVUORI, A., KASTE, M., KARHUNEN, P.J., ERKINJ UNTTI, T. Post-stroke delirium in relation to dementia and long-term mortality. Int] Geriatr Psychiatry, 27, no. 4, 2012, p. 401-408. 27.PUIU, I., ALBU, C.V., TARTEA, E.A., CALBOREAN, V., GHEORMAN, V., DINESCU, S.N., VASILE, R.C., DINESCU, V.C., BICA, E.C., ROMANESCU, F.M., TUDORASCU, D.R. Relationships Between Glial Enteric Cells, Beta-cell Signaling and Tumor Proliferative Activity in Patients with Colorectal Neoplasia, Rev Chim (Bucharest), 69, no 10, 2018, p. 2744-2748.

28.TRASCA, S.P., FLORESCU, C., DINESCU, V.C., PUIU, I., DINESCU, S.N., TUDORASCU, D.R., BICA, C., VASILE, R.C., ROMANESCU, F.M., BUNESCU, M.G., CIOATERA, N., GOANTA, E.V. The Assessment of Percutaneous Coronary Angioplasty versus Coronary Artery Bypass Grafting in Treatment of Left Main Coronary Artery Disease. Rev Chim (Bucharest), 69, no.12, 2018, p.3600-3604.

29.BARBULESCU, A.L., CIUREA, P.L., MITRAN, C., CHISALAU, B.A., PARVANESCU, C.D., FIRULESCU, S.C., BALASOIU, M., BOLDEANU, M.V., POPOVICIU, H., VREJU, F.A., High frequency ultrasonography of the hand versus anti-RA33 evaluation in early rheumatoid arthritis - a pilot study, Med Ultrason, 19, no. 2, 2017, p. 166-171.

30.VREJ U, F.A., CIUREA, M.E., POPA, D., POPA, F., PARVANESCU, C.D., CHISALAU, B.A., BARBULESCU, A.L., PARVANESCU, V., ROSU, A., CIUREA, P.L., Ultrasonography in the diagnosis and management of noninflammatory conditions of the hand and wrist, Med Ultrason, 18, no.1, 2016, p. 90-95.

31.BARBULESCU, A.L., VREJU, A.F., BUGA, A.M., SANDU, R.E., CRIVEANU, C., TUDORASCU, D.R., GHEONEA, I.A., CIUREA, P.L., Vascular endothelial growth factor in systemic lupus erythematosus - correlations with disease activity and nailfold capillaroscopy changes, Rom J Morphol Embryol., 56, no.3, 2015, p.1011-1016.

32.FIRULESCU, S.C., TUDORASCU, D.R., PARVANESCU, C.D., CHISALAU, A.B., BASTIAN, A.E., EFREM, I.C., BARBULESCU, A.L., FORTOFOIU, M.C., CRIVEANU, C., IONESCU, P., DINESCU, S.C., TUDORANCEA, A.D., CIUREA, P.L., VREJU, A.F., The role of skin and muscle biopsy in the diagnosis of main connective tissue diseases, Rom J Morphol Embryol., 59, nr.1, 2018, p.55-64.

33.CIUREA, M.E., CIUREA, R.N., BARBULESCU, A.L., CHISALAU A.B., PARVANESCU, C.D., FIRULESCU, S.C., COVEI BANICIOIU, S., CIUREA, P.L., VREJU, A.F. Intramuscular hemangioma of the arm: ultrasonography and pathology features, Rom J Morph Embryol, 57, nr.2, 2016, p. 521-524.
34.VAN KEULEN, K., KNOL, W., BELITSER, S.V., ZAAL, I.J., VAN DER LINDEN, P.D., HEERDINK, E.R., EGBERTS, T.C.G., SLOOTER, A.J.C. Glucose variability during delirium in diabetic and non-diabetic intensive care unit patients: A prospective cohort study. PLoS One, 13, no. 11, 2018, p. e0205637.

35.HEYMANN, A., SANDER, M., KRAHNE, D., DEJ A, M., WEBERCARSTENS, S., MACGUILL, M., et al. Hyperactive delirium and blood glucose control in critically ill patients. J Int Med Res, 35, 2007, p. 666-677.

36.TAISESCU, C.I., BICIUSCA, V., SAS, L., CAMEN, G., SAS, T., ALBU, C., TAISESCU, O. Changes of Visual Evoked Potentials in Patients with Thyroid Dysfunction, Rev. Chim. (Bucharest), 10, no.3, 2019, p. 961968.

37.TOADER, L.E., ROSU, G.C., CATALIN, B., PIRICI, I., GILCEAVA, I.C., ALBU, V.C., ISTRATE-OFITERU, A.M., MURESANU, D.F., PIRICI, D. Cerebrolysin increases motor recovery and decreases inflammation in a mouse model of autoimmune encephalitis. Romanian journal of morphology and embryology, 59, nr.3, 2018, p.755-762.

38.ANCUTA, C., POMIRLEANU, C., IORDACHE, C., FATU, A.M., POPESCU, E., ANCUTA, E., MIHAILOV, C. Periodontal Disease and Lipid Profile in Systemic Sclerosis: an EUSTAR Cohort Experience. Rev.Chim. (Bucharest), 68, no. 4, 2017, p. 890-893.

39.SAVA, I. SAVA, A. SAPTE, E., MIHAILOV, C., DUMITRESCU, G., POEATA, I., SAVA, F., HABA, D. Intraventricular metastatic clear cell renal carcinoma. Rom J Morphol Embryol., 54, nr.2, 2013, p. 44750.

40.SANDU, R.E., UZONI, A., COMAN, C., POPA-WAGNER, A., Cerebral ischemia in the aged. Limited anti-inflammatory efficacy of the indomethacin treatment. Rom J Morphol Embryol., 56, nr.3, 2015, p. 1111-1117.

41.SANDU, R.E., DUMBRAVA, D., SURUGIU, R., GLAVAN D.G., GRESITA A, PETCU EB., Cellular and Molecular Mechanisms Underlying NonPharmaceutical Ischemic Stroke Therapy in Aged Subjects, Int J Mol Sci., 19, nr.1, 2017, pii: E99. doi: 10.3390/ijms19010099.

42.SANDU, R.E., BUGA, A.M., UZONI, A., PETCU, E.B., POPA-WAGNER, A., Neuroinflammation and comorbidities are frequently ignored factors in CNS pathology, Neural Regen Res., 10, nr.9, 2015, p. 13491355.

43.MUSTAFA, E.R., FIRULESCU, S.C., PARVANESCU, C.D., CHISALAU, B.A., TARTEA, G.C., EFREM, I.C., BARBULESCU, A.L., DINESCU, S.C., CIUREA, P.L., RADU, L, Triple valve endocarditis-a late diagnosis, Journal of Mind and Medical Sciences, 5, nr.1, 2018, p.141-144.

44.FILIPPOU, G., SCIRE, C.A., ADINOLFI, A., DAMJANOV, N.S., CARRARA, G., BRUYN, G.A.W., CAZENAVE, T., D'AGOSTINO, M.A., DELLE SEDIE, A., DI SABATINO, V., DIAZ CORTES, M.E., FILIPPUCCI. E., GANDJ BAKHCH， F., GUTIERREZ, M., MACCARTER, D.K., MICU, M., MOLLER PARERA, I., MOUTERDE, G., MORTADA, M.A., NAREDO, E., PINEDA, C., PORTA, F., REGINATO, A.M., SATULU, I., SCHMIDT, W.A., SERBAN, T., TERSLEV, L., VLAD, V., VREJU, F.A., ZUFFEREY, P., BOZIOS, P., TOSCANO, C., PICERNO, V., IAGNOCCO, A., Identification of calcium pyrophosphate deposition disease (CPPD) by ultrasound: reliability of the OMERACT definitions in an extended set of joints-an international multiobserver study by the OMERACT Calcium Pyrophosphate Deposition Disease Ultrasound Subtask Force, Ann Rheum Dis, 77, nr.8, 2018, p. 1195-1200.

45. POPA-WAGNER, A., BUGA, A.M., TICA, A.A., ALBU, C.V., Perfusion deficits, inflammation and aging precipitate depressive behavior, Biogerontology., 15, nr. 5, 2014, p. 439-448.

46.BOGDAN, C., CUPIDO, A., IANCAU, M., ALBU, C.V., KIRCHHOFF, F., Microglia: first responders in the central nervous system, Rom J Morphol Embryol., 54, nr.3, 2013, p. 467-472.

47.ALBU, C.V., PADUREANU, V., BOLDEANU, M.V., BUMBEA, A.M., ENESCU, A.S., ALBULESCU, D.M., SILOSI, C.A., ENESCU, A., Vascular neurocognitive disorders and the vascular risk factors, Journal of mind and medical sciences, 5, nr.1, 2018, p. 7-15.

\section{Manuscript received:14.11.2018}

